\title{
Cluster relaunch looks to minisatellites
}

Munich. The single back-up satellite of the ill-fated Cluster mission, whose four satellites were on board the Ariane-5 launcher that exploded during its maiden flight last month, is to be prepared for a relaunch. But a decision about when this should take place - and whether the back-up unit should be accompanied by other satellites to allow the major scientific goals of the mission to be achieved - has been deferred to November.

Meeting in London last week, the Science Programme Committee (SPC) of the European Space Agency (ESA) said that a quick launch of the spare satellite, which has been named Phoenix in reference to the ashes from which it will rise, would at least save ESA's commitment to the International Solar Terrestrial Programme, a series of missions flying in different orbits (see Nature 381, 721; 1996). Cluster was intended to take measurements in one of these orbits.

Because of its relatively low cost, estimated at ECU30 million (US\$37 million), this decision will have no impact on ESA's long-term science programme. The SPC, which is made up of delegates from ESA's 14 member states, has decided it needs more time to tackle the thornier - and much more expensive - problem of what steps could be taken to save the other scientific aims of the mission.

Four satellites flying in fixed formation which was Cluster's unique scientific feature - would be required for the three-dimensional analysis of the Earth's electric and magnetic fields as they interact with solar wind particles (see Nature 381, 541; 1996).

The SPC has rejected the request of French scientists to replace exactly the large and identical satellites which comprised Cluster, and has instead asked ESA's executive and its member states to put together cheaper proposals for three additional minisatellites.

These proposals will be presented to the next SPC meeting in November. But the question of how they would be financed - if they are approved - remains.

ESA has not ruled out the possibility of using its own science budget to pay for them. If it were to do so, however, it would certainly have an undesirable knock-on effect on its long-term science programme, Horizons 2000. The SPC has now delayed approval of the plans for the next stage of this programme until November, in order to accommodate any possible delays resulting from a Cluster rescue plan.

But ESA's clearly preferred plan would be for participating member states, which normally pay only for scientific instruments, in this case to pay also for the flight units. Despite tight national budgets in European countries, this is "not a pipe dream", says John Credland, Cluster's project manager.

Several member states that already have

minisatellite programmes, including Britain, Germany, Sweden and Denmark, have expressed interest, he says. Mike Blackwell, a spokesman for the British National Space Centre, says that it is far too early to say if interest will be turned into cash. "But there is at least a positive mood in the UK" for such an investment, he adds.

The launch date for Phoenix could depend on whether such a multisatellite mission is approved. The predominant view in the SPC is that it should be flown as soon as possible, to avoid losing any further time in gathering data. Multipoint recording would then begin as soon as Phoenix is joined by its companion flight units.

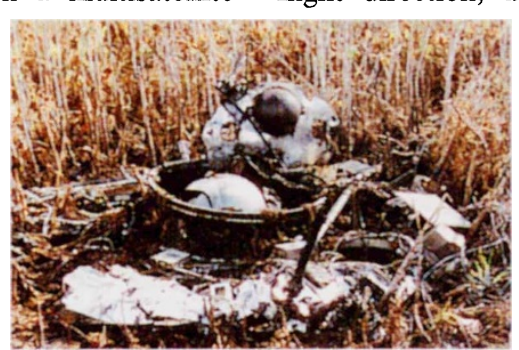

Fallen to Earth: remains of Cluster in

But some members of the committee fear that, in such a case, the instruments on Phoenix could deteriorate before the new minisatellites reach orbit. They argue that, if ESA agrees to a four-satellite mission, the satellites should all be launched together.

Credland replies that the instruments are more likely to deteriorate on the ground than in space, where there is no polluting atmosphere. A bigger problem, he says, will be coordinating the preparatory work on four satellites that would almost certainly be produced in different countries.

As well as the launch date, it will also be decided in November whether to fly Phoenix free on the next Ariane-5 qualification flight, whose timing is likely to coincide with the completion of Phoenix next spring. This is the option favoured by ESA's space science directorate, but this time the directorate will argue for closer monitoring of the review process that assesses the launcher's readiness for flight. Last time it was brought into the process only at a late stage.

A report on the investigation of the cause of Ariane-5's failure will be published next week. It is expected to put the blame on a crucial piece of software in the control of flight direction, used successfully on the much smaller Ariane 4. ESA officials are known to consider that this type of fault should have been picked up at an early stage.

The SPC also learnt last week that plans to restructure ESA, requested by Europe's space ministers last November as a means of increasing efficiency, have been modified. This followed objections from David Southwood, professor of physics at Imperial College, London, and chairman of the committee, who had argued that the proposed separation of planning and implementation in ESA's science programme - the only mandatory activities of the agency - would jeopardize the reliability of long-term planning (see Nature 381, 353; 1996).

Jean-Marie Luton, ESA's director general, is now suggesting an interim plan, under which the whole of the space science directorate would come under the larger umbrella of a new planning directorate, to include all of ESA's activities including Earth observation, telecommunications and utilization of the international space station.

Alison Abbott

\section{India appoints 'part-time' science minister}

New Delhi. The appointment by India's newly elected United Front government of a part-time minister to look after the country's huge science and technology enterprise has disillusioned the scientific community. Indian scientists had been expecting the new government to give greater priority to science than did the previous Congress government, and now feel let down.

The new minister is 57-year-old Yoginder K. Alagh, an economist trained in the United States who was vice-chancellor of the Jawaharlal Nehru University in New Delhi before he joined the council of ministers last week. As a minister of state without cabinet rank, Alagh is primarily responsible for planning and programme implementation. He has been given the science ministry as an "additional charge".
"Non-appointment of a full-time minister is a clear sign that science is not high in the agenda of the new government," says a senior official in the science ministry. He says it is sad because science did not get the attention it deserved even when it had a full-time science minister in the Congress government.

In the past five years, universities and publicly funded laboratories have been run on a shoestring budget. In real terms, funding, as a percentage of gross domestic product, dropped from 0.93 per cent in 1989 to 0.83 per cent last year. Of the 70 billion rupees (US\$2 billion) spent on research and development in 1995, the central government's contribution was only 50 per cent - the rest came from the states and industry. 